\title{
Lusioersily
}

\section{Photocatalytic and electrochemically assisted photocatalytic oxidation of formic acid on TiO2 films under UVA and UVB irradiation}

McMurray, TA., Byrne, JA., Dunlop, PSM., \& McAdams, ET. (2005). Photocatalytic and electrochemically assisted photocatalytic oxidation of formic acid on TiO2 films under UVA and UVB irradiation. Journal of Applied Electrochemistry, 35(7-8), 723. https://doi.org/10.1007/s10800-005-1397-1

Link to publication record in Ulster University Research Portal

Published in:

Journal of Applied Electrochemistry

Publication Status:

Published (in print/issue): 01/01/2005

DOI:

10.1007/s10800-005-1397-1

\section{Document Version}

Author Accepted version

\section{General rights}

Copyright for the publications made accessible via Ulster University's Research Portal is retained by the author(s) and / or other copyright owners and it is a condition of accessing these publications that users recognise and abide by the legal requirements associated with these rights.

\section{Take down policy}

The Research Portal is Ulster University's institutional repository that provides access to Ulster's research outputs. Every effort has been made to ensure that content in the Research Portal does not infringe any person's rights, or applicable UK laws. If you discover content in the Research Portal that you believe breaches copyright or violates any law, please contact pure-support@ulster.ac.uk. 


\title{
Photocatalytic and electrochemically assisted photocatalytic oxidation of formic acid on $\mathrm{TiO}_{2}$ films under UVA and UVB irradiation
}

\author{
T.A. McMURRAY*, J.A. BYRNE, P.S.M. DUNLOP and E.T. McADAMS \\ NIBEC, University of Ulster at Jordanstown, BT37 0QB, Northern Ireland, UK \\ (*author for correspondence, e-mail: TA.McMurray@ulster.ac.uk; fax + 442890366863 )
}

Received 16 August 2004; accepted in revised form 15 November 2004

Key words: electrochemically assisted photocatalysis, formic acid, photocatalysis, titanium dioxide, UVA, UVB

\begin{abstract}
Titanium dioxide $\left(\mathrm{TiO}_{2}\right)$ photocatalysis is a possible alternative/complementary technology for water purification. Attempts to increase the overall efficiency of the process include using higher energy UV to gain better quantum efficiency and electrochemically assisting the process by the application of an external electrical potential. In this work, nanocrystalline $\mathrm{TiO}_{2}$ films, prepared on borosilicate glass and indium-doped tin oxide (ITO) borosilicate glass, were used to investigate the photocatalytic and electrochemically assisted photocatalytic oxidation of formic acid under UVA and UVB irradiation. The experiments were carried out in a stirred tank reactor with high mass transfer characteristics. The rate of formic acid oxidation under UVB irradiation was $30 \%$ greater as compared to UVA irradiation. A maximum $\Phi_{\text {app }}$ of $9 \%$ was obtained under UVA irradiation in $100 \% \mathrm{O}_{2}$ under open circuit or $+1.0 \mathrm{~V}$ (SCE) applied potential. A maximum $\Phi_{\text {app }}$ of $20.3 \%$ was obtained under UVB irradiation with $100 \% \mathrm{O}_{2} \mathrm{using}^{\mathrm{TiO}} \mathrm{O}_{2}$ on borosilicate glass. $\Phi_{\text {app }}$ was $19 \%$ for $+1.0 \mathrm{~V}, 100 \% \mathrm{O}_{2}$, using $\mathrm{TiO}_{2}$ on ITO borosilicate glass under UVB irradiation. The increase in oxidation rates and $\Phi_{\text {app }}$ with $\mathrm{UVB}$ irradiation are due to the higher extinction coefficient of $\mathrm{TiO}_{2}$ at shorter wavelengths and/or the promotion of conduction band electrons to higher more stable states, thus reducing the rate of recombination of charge carriers. The use of a UVB source as compared to a UVA source results in a significant increase in the rate of oxidation and increased apparent quantum yields, however, a cost analysis of the process would be required to determine the economic viability of employing UVB sources. Electrochemically assisted photocatalysis may prove beneficial in large-scale reactors where mass transfer limitations exist.
\end{abstract}

\section{Introduction}

Titanium dioxide $\left(\mathrm{TiO}_{2}\right)$ photocatalysis is a possible alternative/complementary technology for water purification [1-3]. $\mathrm{TiO}_{2}$ absorbs electromagnetic radiation of $\lambda \leq 387 \mathrm{~nm}$ (anatase) and $\lambda \leq 413 \mathrm{~nm}$ (rutile), which causes excitation of valence band (vb) electrons to the conduction band $(\mathrm{cb})$ leaving positive holes $\left(\mathrm{h}^{+}\right)$in the $\mathrm{vb}$. The flat band potential $\left(E_{\mathrm{fb}}\right)$ for colloidal anatase particles has been reported to be $-0.52 \mathrm{~V}$ (vs. SCE) at $\mathrm{pH} 3$ [4], which gives an electrochemical reduction potential of $\mathrm{vb} \mathrm{h}^{+}$as $+2.68 \mathrm{~V}$. Therefore, the $\mathrm{vb} \mathrm{h}^{+}$are able to oxidise water to yield hydroxyl radicals or to oxidise hole acceptors directly (e.g. organic pollutants in water) at the surface, and the $\mathrm{cb}$ is negative enough to reduce oxygen.

There are numerous reports of attempts to increase the overall efficiency of the process e.g. improved reactor design to increase mass transfer efficiency [5], surface doping with noble metals to catalyse electron transfer reactions at the surface [6], annealing the catalyst at elevated temperatures to improve crystallinity and particle size [7], using higher energy UV to gain better quantum efficiency [8], the use of pulsed irradiation [9], exploiting the use of alternative electron acceptors to $\mathrm{O}_{2}$ [10], and/or electrochemically assisting the process by the application of an external electrical bias [11].

Previously we reported the use of a stirred tank reactor with immobilised, nano-structured, $\mathrm{TiO}_{2}$ to investigate the intrinsic kinetics of oxidation of formic acid and oxalic acid as a function of operational parameters [12]. Here we report the results of an investigation into the effect of electrochemically assisted photocatalysis (EAP) compared to "open circuit" photocatalysis under UVA and UVB irradiation.

\section{Experimental}

\subsection{Immobilisation of $\mathrm{TiO}_{2}$}

Borosilicate glass plates $(110 \mathrm{~mm} \times 110 \mathrm{~mm}$, Instrument Glasses, UK) were dipcoated from a $5 \% \mathrm{TiO}_{2}$ (Degussa $P 25)$ methanol suspension at a constant withdrawal rate of $4.3 \mathrm{~mm} \mathrm{~s}^{-1}$ [12]. The plates were dried after each coat 
using an IR lamp. This procedure was repeated to produce plates with a range of $\mathrm{TiO}_{2}$ loadings. One side of the coated plate was cleaned to remove the $\mathrm{TiO}_{2}$ and the plates were annealed in air at $673 \mathrm{~K}$ for $1 \mathrm{~h}$. Gravimetric analysis of the plates was used to determine the $\mathrm{TiO}_{2}$ loading. For experiments involving EAP, ITO borosilicate glass $(110 \mathrm{~mm} \times 110 \mathrm{~mm}, 1.1 \mathrm{~mm}$ thick, resistivity of $180 \Omega$ 's per square, Donnelly Corporation, USA) was coated with $\mathrm{TiO}_{2}$ (Degussa P25) using an electrophoretic coating procedure previously reported [13]. An electrical contact was made to the corner of the ITO glass by attaching a piece of copper wire using silver loaded conducting epoxy. The transmission spectra of the borosilicate and ITO coated borosilicate glass substrate are given in Figure 1.

\subsection{Photocatalytic and EAP experiments}

A custom built stirred tank photo-reactor, previously reported [12], was used in all experiments and was adapted for use as a one-compartment photoelectrochemical cell by the attachment of a carbon bush contact to the shaft of the stainless steel propeller (Figure 2). The catalyst plates were irradiated from below using either two PL-S 9W/10 UV-A fluorescent lamps or two PL-S 9W/12 UVB fluorescent lamps (Philips) positioned at a distance of $2.5 \mathrm{~cm}$ away from the $\mathrm{TiO}_{2}$ glass plate. The spectral responses for both types of lamps, determined using a spectroradiometer (Gemini 180, Jobin Yvon) are given in Figure $3 a$ and $b$. The PL-S 9W/10 UVA fluorescent lamps are reported to have a stable output between 350 and $400 \mathrm{~nm}$ (peak emission at $370 \mathrm{~nm}$ ), the UVB/UV ratio is less than $0.1 \%$ and the lamps have an output of $1.9 \mathrm{~W}$ of UVA radiation. The PL-S 9W/12 UVB fluorescent lamps are reported to have a stable output between 265 and $380 \mathrm{~nm}$ (peak emission $310 \mathrm{~nm}$ ) and an output of $0.75 \mathrm{~W}$ of UVB radiation [14].

The light intensity entering the reactor was determined by potassium ferrioxalate actinometry [15]. For UVA and UVB irradiation the incident photon flux was determined to be $3.28 \times 10^{-8}$ Einstein $\mathrm{cm}^{-2} \mathrm{~s}^{-1}$ and $2.00 \times 10^{-8}$ Einstein $\mathrm{cm}^{-2} \mathrm{~s}^{-1}$, respectively. In a typical experiment, the UV lamps were allowed to stabilise for $20 \mathrm{~min}$ before the catalyst was irradiated. $200 \mathrm{~cm}^{3}$ of aqueous formic acid $\left(5.3 \times 10^{-3} \mathrm{~mol} \mathrm{dm}^{-3}\right)$ was added to the reactor and equilibrated for $15 \mathrm{~min}$ in the dark with sparging. At $t=0 \mathrm{~s}$, a $1.5 \mathrm{~cm}^{3}$ sample was removed and the electrode illuminated. Samples were taken every $15 \mathrm{~min}$ thereafter, usually for a period of $2 \mathrm{~h}$. Formic acid was sparged with either, oxygen, air or oxygen free nitrogen (OFN) at a flow rate of $900 \mathrm{~cm}^{3} \mathrm{~min}^{-1}$. The illuminated catalyst area was $56.7 \mathrm{~cm}^{2}$.

The electrode potential and short-circuit current were recorded using a multimeter with data logging facility (Keithly). Linear sweep voltammetry (LSV) and fixed potential experiments were carried out using a potentiostat under PC control (Autolab PG40). All potentials are reported vs SCE.

The concentration of formic acid was determined by HPLC with an Aminex HPX-87H Ion Exclusion Column $(300 \mathrm{~mm} \times 7.8 \mathrm{~mm}$ id, Bio-Rad $)$ with guard column, a P2000 pump, AS 1000 autosampler, LIS $\mathrm{UV} /$ Vis detector, and PC1000 software (Thermoquest). Conditions were as follows: mobile phase was $1 \times 10^{-3} \mathrm{~mol} \mathrm{dm}^{-3} \mathrm{H}_{2} \mathrm{SO}_{4} \mathrm{pH} 1.5$ at a flow rate of $0.8 \mathrm{~cm}^{3}$ per $\min ^{-1}$ : column temperature was $30^{\circ} \mathrm{C}$ : injection volume was $100 \mu \mathrm{l}$ : UV detection at $\lambda$ $210 \mathrm{~nm}$.

\section{Results and discussion}

\subsection{Photocatalytic oxidation rate of formic acid under $U V A$ and $U V B$ irradiation}

Previously we reported the effect of catalyst loading using UVA irradiation, and it was found that the rate of oxidation of formic acid increased with increasing catalyst loading up to an optimum loading of ca.

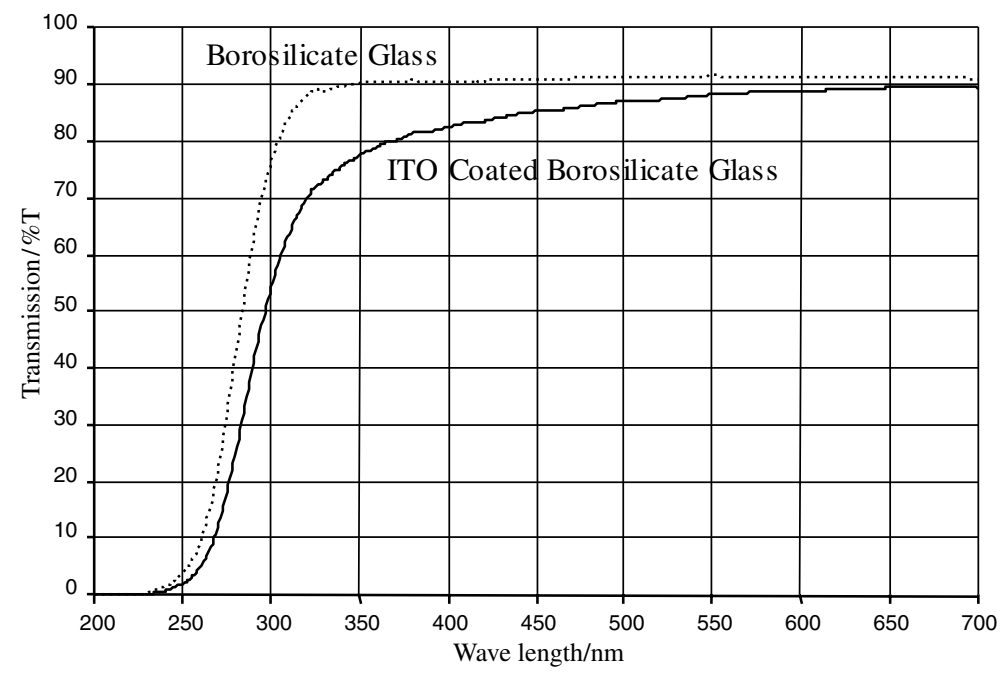

Fig. 1. UV transmittance spectra for borosilicate and ITO-coated borosilicate glass substrates. 


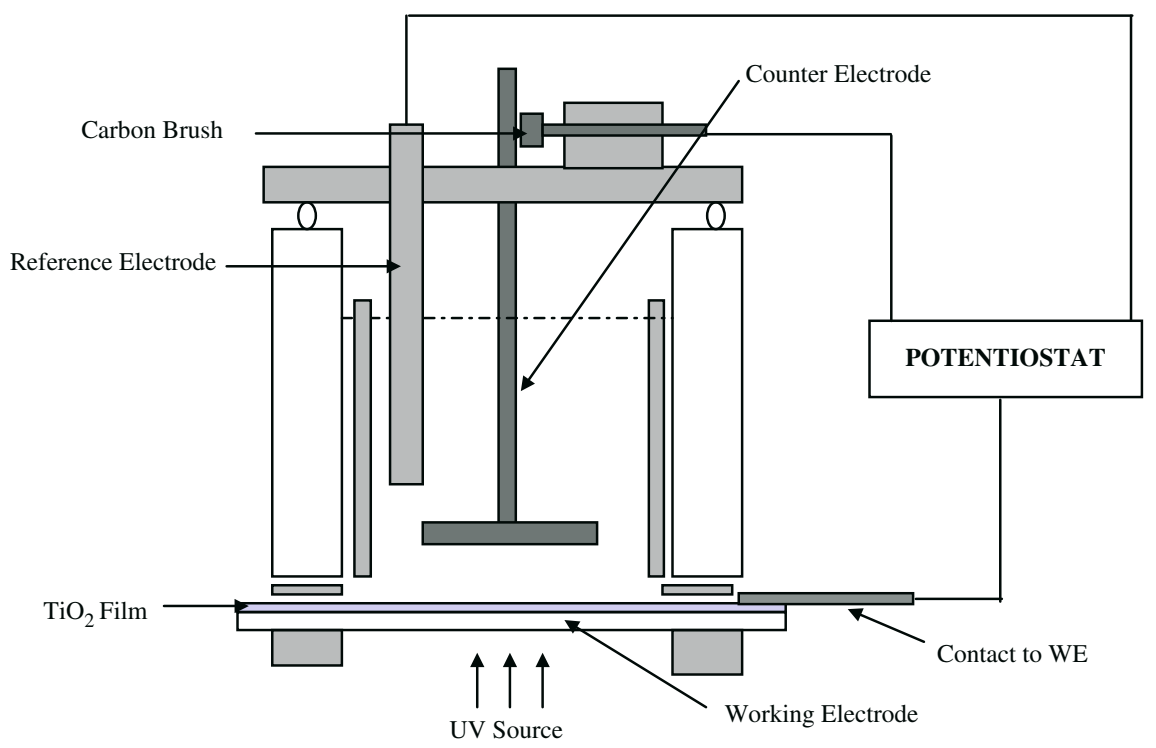

Fig. 2. Schematic diagram of modified stirred tank reactor as a photoelectrochemical cell.
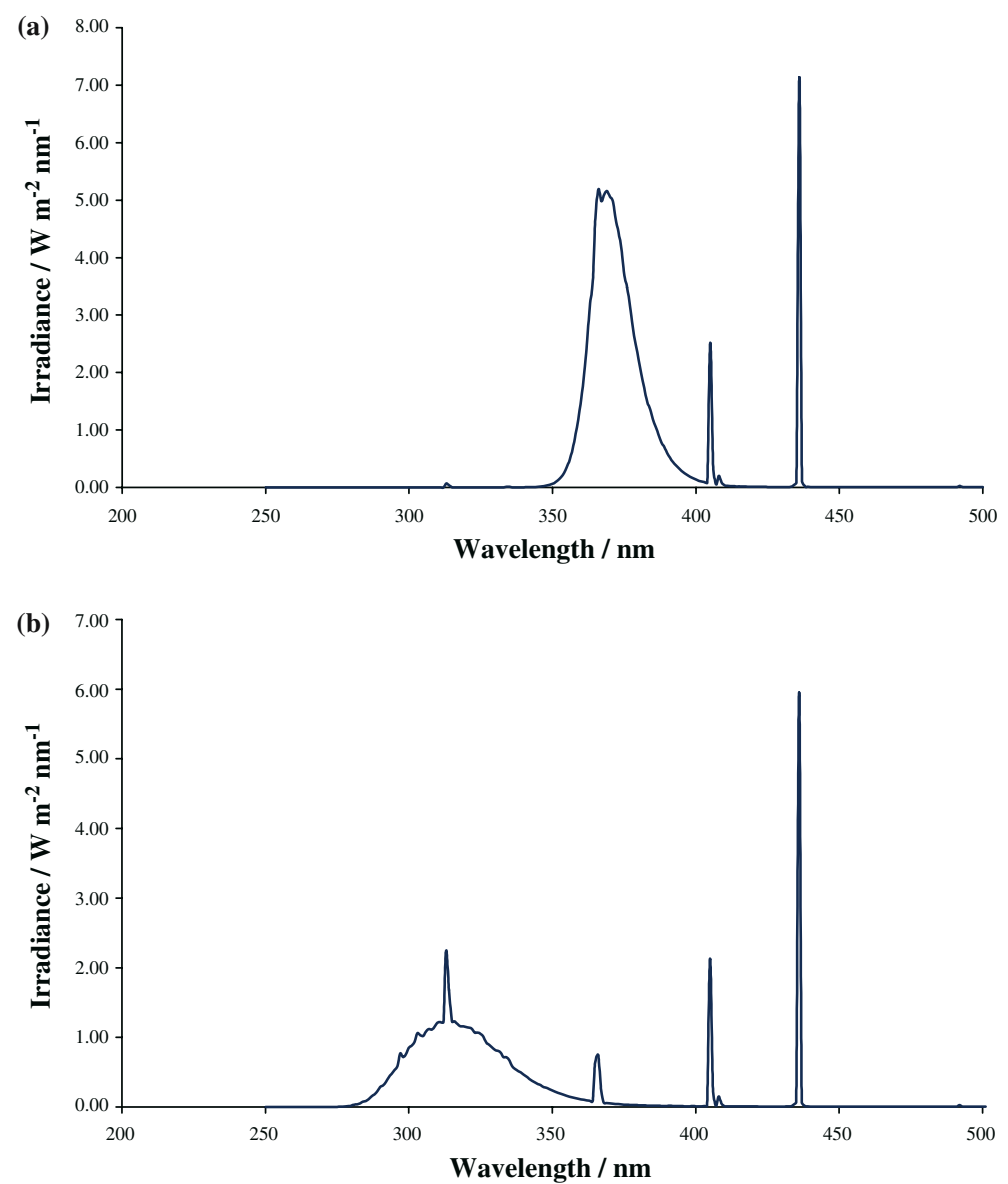

Fig. 3. Spectral Output for (a) UVA source and (b) UVB source.

$1.17 \mathrm{mg} \mathrm{cm}^{-2}$, with no further increase observed above this catalyst loading. The effect of catalyst loading on the rate of formic acid oxidation was investigated under UVB irradiation and it was found that there was a small increase in the initial rate of oxidation with increasing catalyst loading, up to an optimum loading of ca. $1.17 \mathrm{mg} \mathrm{cm}^{-2}$. Any further increase above this loading caused a decrease in the rate of oxidation (Figure 4). A similar trend has been reported by other workers [16, 17].

While the rate of oxidation of formic acid under UVB irradiation was not markedly dependent on catalyst loading, the rate at all catalyst loadings was much greater than that observed under UVA irradiation. For 


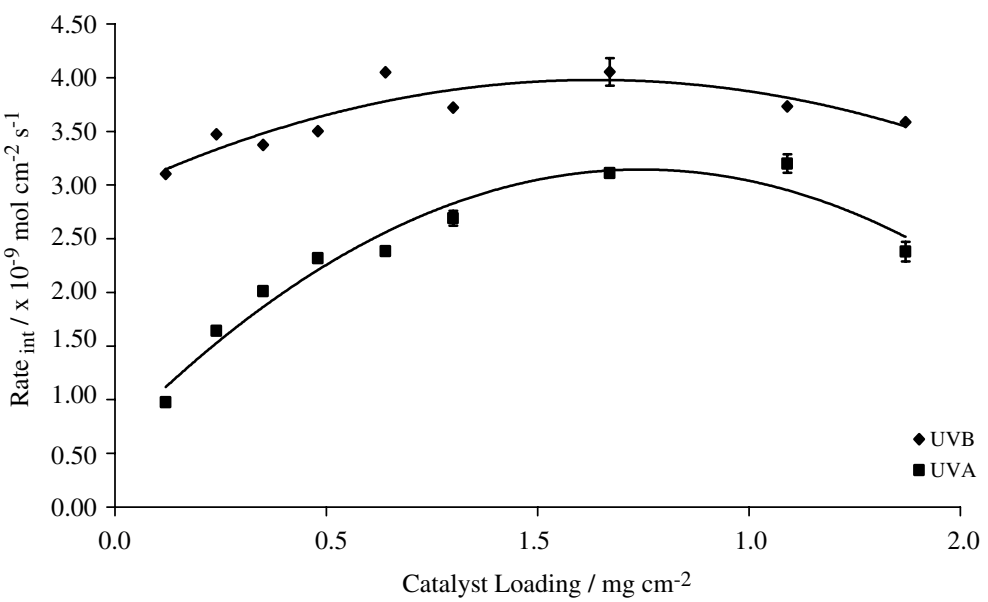

Fig. 4. Effect of UVA/UVB irradiation on initial rate of formic acid degradation at varying $\mathrm{TiO}_{2}$ catalyst loadings.

example, the rate at the lowest catalyst loading investigated $\left(0.12 \mathrm{mg} \mathrm{cm}^{-2} \mathrm{TiO}_{2}\right)$ under UVB irradiation corresponds to that obtained with the optimum catalyst loading $\left(1.17 \mathrm{mg} \mathrm{cm}^{-2} \mathrm{TiO}_{2}\right)$ determined under UVA irradiation i.e. rate $=3.1 \times 10^{-9} \mathrm{~mol} \mathrm{~cm}^{-2} \mathrm{~s}^{-1}$. UVB irradiation resulted in a $30 \%$ increase in the rate of oxidation compared to UVA irradiation, when the catalyst loading was $1.17 \mathrm{mg} \mathrm{cm}^{-2}$.

The apparent quantum yield was calculated using Equation 1;

$$
\begin{aligned}
\Phi_{\text {app }}= & \text { Rate }_{\text {initial }}\left(\mathrm{mol} \mathrm{cm}^{-2} \mathrm{~s}^{-1}\right) / \text { photon flux } \\
& \left(\text { Einstein } \mathrm{cm}^{-2} \mathrm{~s}^{-1}\right)
\end{aligned}
$$

Table 1 gives Rate initial $_{\text {and }} \Phi_{\text {app }}$ for UVA and UVB irradiation as a function of catalyst loading. $\Phi_{\text {app }}$ was higher in all cases with UVB irradiation in comparison with UVA. $\Phi_{\text {app }}$ increases with catalyst loading reaching a maximum which corresponds to the optimum film thickness. For UVB irradiation the $\Phi_{\text {app }}$ was not markedly dependent on the catalyst loading, with the highest $\Phi_{\text {app }}$ obtained at catalyst loading in the range of $0.64-1.59 \mathrm{mg} \mathrm{cm}^{-2}$. The maximum $\Phi_{\text {app }}$ obtained for UVB was $20.3 \%$ compared to that obtained for UVA being $9.5 \%$, a factor of 2.1 greater.
A similar effect was reported for the photocatalytic oxidation of phenol [18] and with 4-chlorophenol [8] where the quantum yield increased with decreasing wavelength. Blazkova et al. reported that they could increase in the quantum efficiency for phenol oxidation using immobilised $\mathrm{TiO}_{2}$ sol-gel films by a factor of 1.13 by using irradiation of $320 \mathrm{~nm}$ instead of $350 \mathrm{~nm}$. Stafford et al. reported a variation in the quantum yields for 4-chlorophenol oxidation from $0.3 \%$ for $380 \mathrm{~nm}$ light to $7 \%$ for $300 \mathrm{~nm}$ using a $\mathrm{TiO}_{2}$ slurry system (a factor increase of 23.3).

Stafford et al. [8] proposed that $\mathrm{e}^{-}$which absorb more energetic photons are promoted to an energy level higher than the conduction band minimum, and are therefore less likely to recombine with the generated $\mathrm{h}^{+}$. Therefore, at lower wavelengths such as $310 \mathrm{~nm}$ there is more energy available for the promotion of electrons into a higher level than the conduction band minimum. The observed higher quantum yields are as a result of reduced electron/hole pair recombination. It should be noted that absorption coefficient of $\mathrm{TiO}_{2}$ increases with decreasing wavelength with maximum absorption at $\lambda 250 \mathrm{~nm}$ [19].

\subsection{Electrochemically assisted photocatalysis}

3.2.1. Photoelectrochemical response of $\mathrm{TiO}_{2}$ electrodes Linear sweep voltammetry (LSV) was used to measure the current-potential $(I-E)$ response of the

Table 1. Initial rate and $\Phi_{\text {app }}$ for UVA and UVB irradiation as a function of catalyst loading (Initial concentration of formic acid was $5.3 \times 10^{-3} \mathrm{~mol} \mathrm{dm}^{-3}$ )

\begin{tabular}{lllll}
\hline Wcat $/ \mathrm{mg} \mathrm{cm}^{-2}$ & \multicolumn{2}{l}{} & & UVB \\
\cline { 2 - 3 } & Rate $_{\text {int }} / 10^{-9} \mathrm{~mol} \mathrm{~cm}^{-2} \mathrm{~s}^{-1}$ & $\Phi_{\text {app }}$ & & Rate $_{\text {int }} / 10^{-9} \mathrm{~mol} \mathrm{~cm}^{-2} \mathrm{~s}^{-1}$ \\
1.87 & 2.38 & 0.073 & 3.59 & 0.179 \\
1.56 & 3.02 & 0.092 & 3.73 & 0.187 \\
1.17 & 3.11 & 0.095 & 4.06 & 0.203 \\
0.80 & 2.69 & 0.082 & 3.72 & 0.186 \\
0.64 & 2.38 & 0.073 & 4.05 & 0.202 \\
0.48 & 2.32 & 0.071 & 3.50 & 0.175 \\
0.35 & 2.01 & 0.061 & 3.37 & 0.067 \\
0.024 & 1.64 & 0.050 & 3.47 & 0.174 \\
0.012 & 0.98 & 0.030 & 3.10 & 0.155 \\
\hline
\end{tabular}


$\mathrm{TiO}_{2}$ electrode in the dark and under irradiation, in the presence of formic acid. The potential was swept from -1.0 to $+2.0 \mathrm{~V}$ at a sweep rate of $0.01 \mathrm{~V} \mathrm{~s}^{-1}$. The electrode behaved as an n-type semiconductor with little anodic current observed in the dark and an anodic current observed under irradiation, which increased with increasing positive potential. The $I-E$ response is atypical in that the LSV would normally reach a maximum current at around $+0.5 \mathrm{~V}$ more positive than the onset for anodic current [20-24], and is probably due to a combination of the high resistivity of the conducting glass and low conductivity of the solution. However, this work is aimed at addressing potable water treatment and the addition of supporting electrolyte is therefore not appropriate. The photocurrent is attributed to the photogeneration of minority charge carriers $\left(\mathrm{h}^{+}\right)$. It should be noted that no supporting electrolyte was present for these experiments other than the formic acid $\left(5.3 \times 10^{-3} \mathrm{~mol} \mathrm{dm}^{-3}\right)$.

Under oxygen and nitrogen sparging, the $I-E$ responses were similar although the onset for anodic current was shifted positive and the measured photocurrent was less in $\mathrm{O}_{2}$ sparged conditions. $\mathrm{O}_{2}$ is an efficient electron acceptor and scavenges photogenerated electrons from the $\mathrm{TiO}_{2}$ film before they can reach the support electrode [25]. Byrne et al. also suggested that the $\mathrm{O}_{2}$ reacts with the primary radical formed by the one electron oxidation of formic acid [26]. Higher photocurrents were obtained for UVB irradiation than for UVA. Vinodgopal et al. [27] reported that the photocurrent increased with decreasing wavelength following the absorption characteristics of $\mathrm{TiO}_{2}$. No shift for the onset potential was observed in $\mathrm{O}_{2}$ under UVB irradiation as was seen with UVA irradiation. This may be explained in that the photogenerated electrons are produced in the inner layer of the $\mathrm{TiO}_{2}$ closer to the support electrode and are less likely to be scavenged by $\mathrm{O}_{2}$ as they diffuse to the back contact electrode (Figure 5a and b).

\subsubsection{Open circuit potential}

The open circuit potential $\left(E_{\mathrm{OC}}\right)$ for the $\mathrm{TiO}_{2}$ electrode was measured as a function of time in the presence of formic acid under $\mathrm{O}_{2}$, air or OFN sparged conditions. The results are shown in Table 2 for UVA and UVB, respectively. Upon irradiation $E_{\mathrm{OC}}$ shifted negative in all cases with a more negative shift observed with decreasing $\mathrm{O}_{2}$ concentration. Under OFN sparged conditions the electrode potential remained negatively
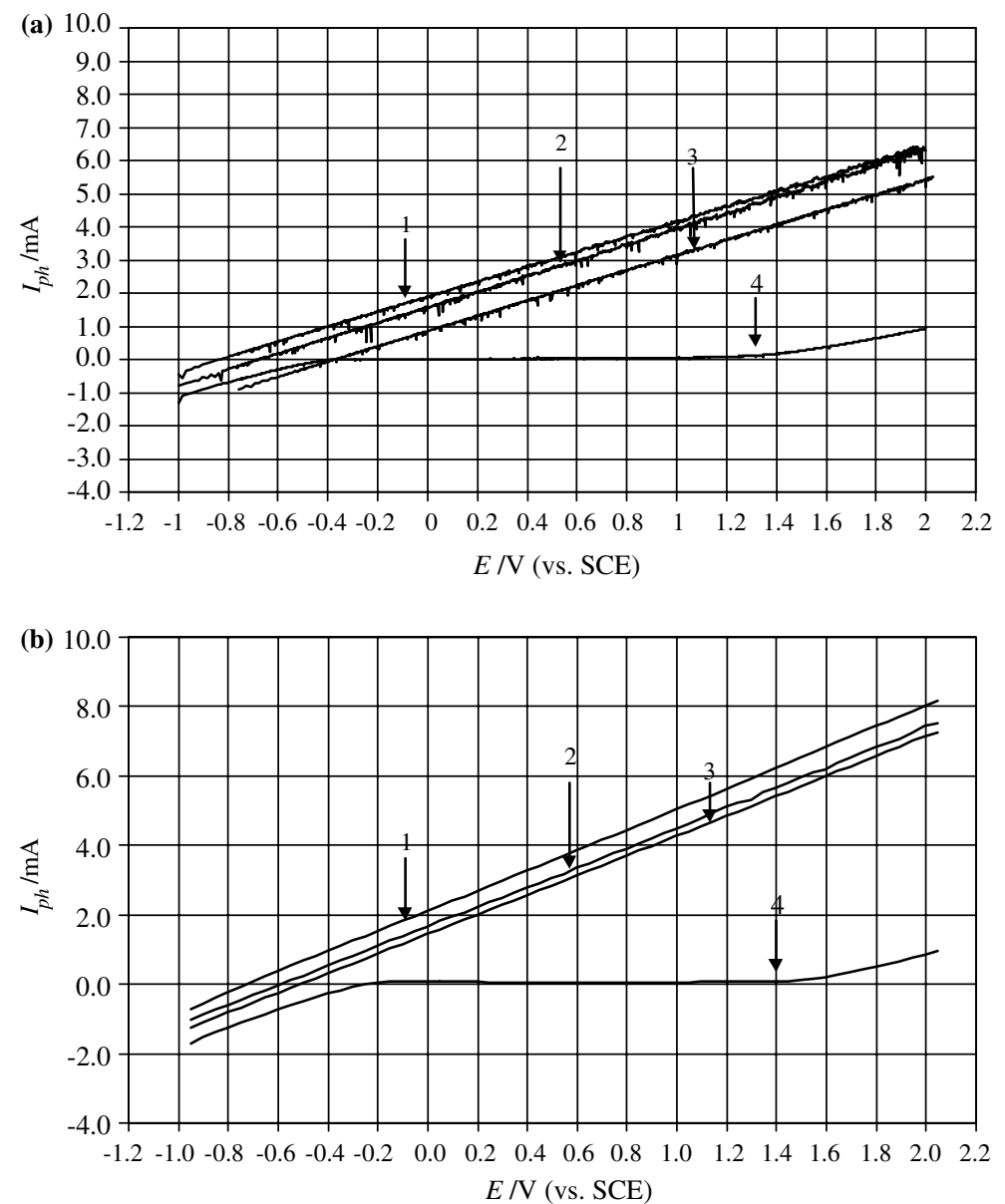

Fig. 5. Linear sweep voltammograms in the presence of formic acid under (a) UVA irradiation [FA] $5.3 \times 10^{-3} \mathrm{~mol} \mathrm{dm}^{-3}$, sweep rate $=0.01 \mathrm{~V} \mathrm{~s}^{-1}\left(1=\right.$ OFN; light, $2=$ air; light, $3=\mathrm{O}_{2}$; light, $4=$ air; dark $)$ and (b) UVB irradiation [FA] $5.3 \times 10^{-3} \mathrm{~mol} \mathrm{dm}^{-3}$, sweep rate $=0.01 \mathrm{~V} \mathrm{~s}^{-1}\left(1=\right.$ OFN; light, $2=$ air; light, $3=\mathrm{O}_{2}$; light, $4=$ air; dark $)$. 
charged even when the light source was switched-off. This negative potential is due to the photogenerated electrons becoming trapped in the conduction band as electron transfer to solution is limited. $E_{\mathrm{OC}}$ was less negative when $\mathrm{O}_{2}$ was present and shifted more positive with time due to the photocatalytic oxidation of formic acid. Gerischer and Heller [28] reported that the removal of conduction band electrons may be rate limiting under certain circumstances i.e. when dissolved $\mathrm{O}_{2}$ concentration is low, the concentration of hole acceptor is high, or the light intensity is high. The measured potentials were more negative under UVB compared to UVA.

\subsubsection{Effect of applied potential on the rate of oxida-} tion Initial rates determined for EAP under $\mathrm{O}_{2}$, air, and OFN sparged conditions are compared with photocatalysis alone i.e. open circuit (OC) under UVA irradiation (Figure 6). Under OC conditions, the rate of photocatalytic oxidation increased as the percentage $\mathrm{O}_{2}$ increased (OFN to 100\%). There was approximately $19 \%$ increase in the oxidation rate between $\mathrm{O}_{2}$ and air sparging.

It was found that the application of $+1.0 \mathrm{~V}$ to the $\mathrm{TiO}_{2}$ electrode increased the oxidation rate of formic acid in OFN by a factor of 17.3, however the oxidation rate under OC conditions is negligible and even under a bias it is still not comparable to that of OC conditions for air or $\mathrm{O}_{2}$ sparging. In air sparged conditions a small increase $(6 \%)$ in the rate was observed although the rate was lower than that measured under $\mathrm{O}_{2}$ saturated $\mathrm{OC}$

Table 2. $E_{\mathrm{OC}}$ for the $\mathrm{TiO}_{2} / \mathrm{ITO}$ electrode (Electrolyte was $5.3 \times 10^{-3} \mathrm{~mol} \mathrm{dm}^{-3}$ formic acid)

\begin{tabular}{llll}
\hline $\mathrm{O}_{2} \%$ & $E_{\mathrm{OC}} / \mathrm{V}$ & & \\
\cline { 2 - 4 } & Dark & UVA & UVB \\
\hline$<1$ & -0.23 & -0.67 & -0.70 \\
20 & +0.06 & -0.49 & -0.56 \\
100 & +0.07 & -0.35 & -0.44 \\
\hline
\end{tabular}

conditions. Under $\mathrm{O}_{2}$ sparged conditions the applied potential had no effect on the rate of oxidation suggesting that electron transfer to $\mathrm{O}_{2}$ is not rate limiting.

A further consideration is electromigration of the pollutant to the $\mathrm{TiO}_{2}$ film. The application of a positive potential will attract the negatively charged ions in solution to the $\mathrm{TiO}_{2}$ film thus increasing mass transfer. However, since the STR exhibits good mass transfer at high propeller speeds, convective mass transfer dominates over electromigration. Increasing the applied potential to $+2.0 \mathrm{~V}$ did not result in any further enhancement of the rate under air sparged conditions.

Other workers have reported an increase in the rate of oxidation for formic acid with the application of a potential. Byrne et al. [29] found that a $+1.0 \mathrm{~V}$ increased the rate under both $\mathrm{O}_{2}$ and air sparged conditions by a factor of $1.09(8.5 \%)$ and 1.37 (37.5\%), respectively, in a flow reactor. Kim and Anderson reported that maximum efficiency could be obtained with the application of $0.0 \mathrm{~V}$ [30]. In a subsequent paper, Kim and Anderson [31] reported a 2-fold increase in the rate of reaction, under oxygenated conditions, when a potential of $+0.3 \mathrm{~V}$ was applied. Candal et al. [32] reported a noticeable increase in the rate of oxidation for formic acid in oxygenated conditions when the applied potential was increased to $+1.0 \mathrm{~V}$, however, increasing the applied potential further to $+2.0 \mathrm{~V}$ resulted in only a limited increase compared to that obtained for $+1.0 \mathrm{~V}$. However, it has been reported that the application of $+0.3 \mathrm{~V}$ to the $\mathrm{TiO}_{2}$ electrode actually resulted in a decrease in the rate of oxidation of sodium dodecylbenzenesulphonate and benzenesulphonate, compared to that found under OC conditions [33].

Short circuit experiments (SC) were carried out by short-circuiting the $\mathrm{TiO}_{2}$ electrode through an ammeter, to the counter electrode. The potential of the working electrode was measured against the reference electrode. No increase in the oxidation rate in was observed in comparison with $\mathrm{OC}$ and $+1.0 \mathrm{~V}$.

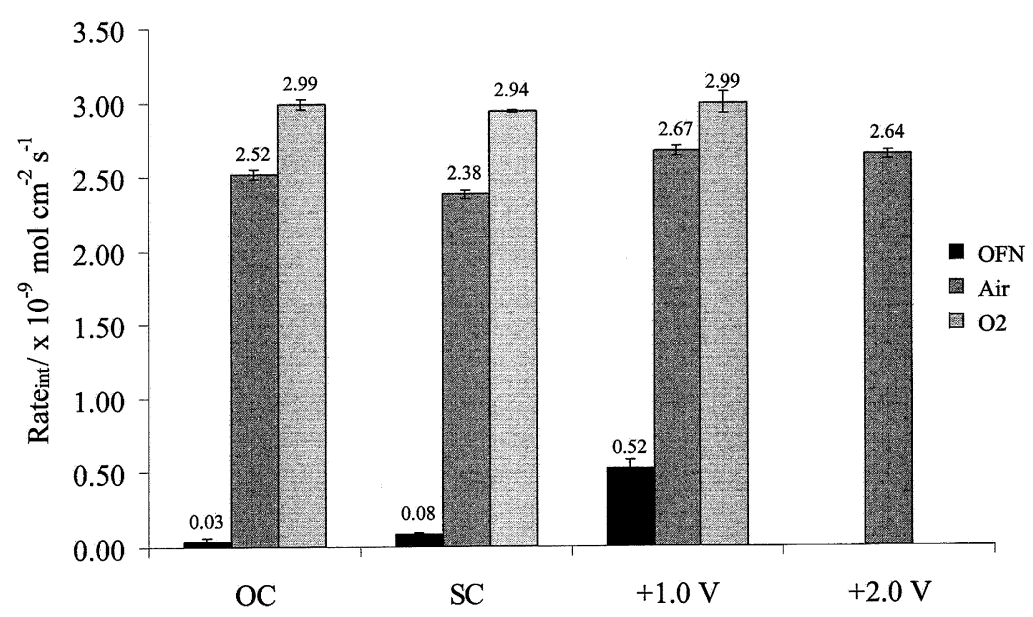

Fig. 6. Comparison of $\mathrm{OC}, \mathrm{SC},+1.0 \mathrm{~V}$ and $+2.0 \mathrm{~V}$ (vs SCE) in $\mathrm{OFN}$, air and $\mathrm{O}_{2}$ sparged solutions under UVA irradiation. 
At OC under UVB irradiation, the rate of photocatalytic oxidation increased as the percentage $\mathrm{O}_{2}$ increased (OFN, 20\% $\mathrm{O}_{2}, 100 \% \mathrm{O}_{2}$ ) (Figure 7). There was approximately a $22 \%$ increase in the oxidation rate between $\mathrm{O}_{2}$ and air sparging. This was similar to that of UVA irradiation were a $19 \%$ increase was observed between $\mathrm{O}_{2}$ and air sparged conditions. Under OFN sparging the decrease in formic acid concentration was negligible. In all cases, the rate measured under UVB irradiation was greater than that of UVA irradiation with a $20 \%$ increase in the rate of formic acid oxidation in $100 \% \mathrm{O}_{2}$ compared to $20 \% \mathrm{O}_{2}$. This may be due to a combination of factors i.e. higher extinction coefficient of $\mathrm{TiO}_{2}$ for UVB and less recombination due to conduction band electrons being promoted to higher more stable states.

Under OFN sparging the application of a positive bias increased the oxidation rate by a factor of 10 , however this rate is still not comparable with the rates observed at $\mathrm{OC}$ with air or $\mathrm{O}_{2}$. In air-sparged conditions the application of a positive potential increased the rate by $\sim 15 \%$ and in $\mathrm{O}_{2}$ sparged conditions the application of a positive bias increased the rate of oxidation by $\sim 4 \%$ compared to OC. There was a small increase in the rate under SC conditions as compared to OC conditions. Surprisingly, increasing the applied potential more positive than $+1.0 \mathrm{~V}$ resulted in a small decrease in the rate. Candal et al. found [32] that the increasing the potential from $+1.0 \mathrm{~V}$ to $+2.0 \mathrm{~V}$ caused only a limited increase in the oxidation rate. Krysa and Jirkovsky [34] found that the oxidation rate of oxalic acid increased with increasing potential up to $+0.5 \mathrm{~V}$ with a decrease in the rate for potentials more positive than this.

\subsubsection{Photocurrent response of $\mathrm{TiO}_{2}$ electrodes}

The photocurrent response was recorded for all experiments under applied bias. Similar patterns were observed for both UVA and UVB irradiation with respect to photocurrent. Under OFN sparged conditions the initial photocurrent recorded was $\sim 4.1 \mathrm{~mA}$ for UVA and $\sim 5.0 \mathrm{~mA}$ for UVB. This remained steady for the duration of the experiment. Under both $\mathrm{O}_{2}$ and air sparged conditions, the initial photocurrent (air: $\sim 4.1 \mathrm{~mA}$ for UVA and $\sim 4.4 \mathrm{~mA}$ for UVB; $\mathrm{O}_{2}$ : $\sim 3.9 \mathrm{~mA}$ for UVA and $\sim 4.0 \mathrm{~mA}$ for UVB) dropped slowly with a sudden decrease towards the end of the experiment. A decrease in photocurrent over time would be expected as the concentration of formic acid is decreasing. When the formic acid concentration had fallen below detectable limits the photocurrent was less than $0.01 \mathrm{~mA}$. The lowest photocurrent observed was in $100 \% \mathrm{O}_{2}$ because of the $\mathrm{O}_{2}$ scavenging radicals and $\mathrm{cb}$ $\mathrm{e}^{-}$. Other studies have reported decreasing photocurrents over time [32, 35].

\subsection{Control experiments}

Control experiments were carried out under both UVA and UVB irradiation in the presence and absence of $\mathrm{TiO}_{2}, \mathrm{O}_{2}$, and light. No significant oxidation was observed unless $\mathrm{TiO}_{2}$, light and $\mathrm{O}_{2}$ were present.

Control experiments were also carried out under an applied potential of $+1.0 \mathrm{~V}$ and $\mathrm{O}_{2}$ sparged conditions, with and without the presence of $\mathrm{TiO}_{2}$ and light. No appreciable oxidation occurred unless catalyst and light were present. No significant oxidation of formic acid occurred on the conductive ITO glass alone, either by photolysis, photocatalysis (on tin oxide), or by direct electrochemical oxidation.

\subsection{Comparison of UVA and UVB irradiation}

Table 3 presents the overall data in order to compare the effect of UVA and UVB irradiation under OC, SC and applied potentials, in OFN, air and $\mathrm{O}_{2}$ sparged conditions. In OC conditions the highest oxidation rate was obtained with $\mathrm{O}_{2}$ and UVB irradiation. Similar rates were observed for air sparging under UVB irradiation compared to that observed for $\mathrm{O}_{2}$ sparging and UVA

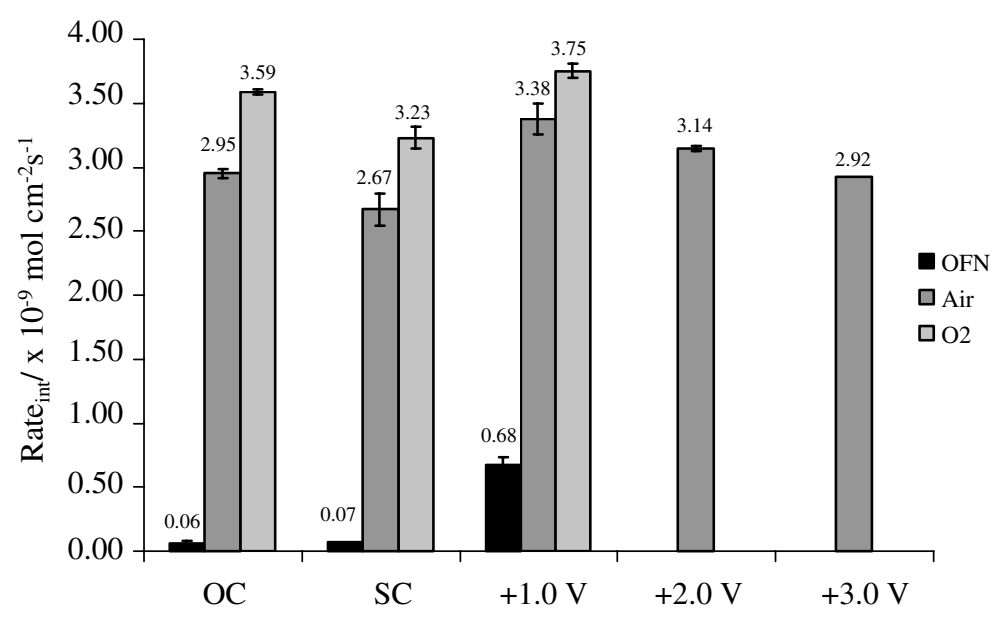

Fig. 7. Comparison of $\mathrm{OC}, \mathrm{SC}$ and $+1.0,+2.0$ and $+3.0 \mathrm{~V}$ (vs $\mathrm{SCE}$ ) in $\mathrm{OFN}$, air and $\mathrm{O}_{2}$ sparged solutions under UVB irradiation. 
Table 3. Summary table of data obtained for UVB and UVB illumination under OC, $\mathrm{SC},+1.0,+2.0$ and $+3.0 \mathrm{~V}$ (vs. SCE) conditions in OFN, air and $\mathrm{O}_{2}$ sparged solutions

\begin{tabular}{|c|c|c|c|c|c|c|c|c|c|}
\hline \multirow[t]{2}{*}{ Conditions } & \multirow[t]{2}{*}{$\mathrm{O}_{2} / \%$} & \multicolumn{4}{|l|}{ UVA } & \multicolumn{4}{|l|}{ UVB } \\
\hline & & $\begin{array}{l}\mathrm{E}_{\text {anode }} \\
\text { (intial) } / \mathrm{V}\end{array}$ & $\underset{\text { (initial) } / \mathrm{mA}}{\mathrm{I}_{\mathrm{ph}}}$ & $\begin{array}{l}\text { Rate/ } \\
\text { mol cm }{ }^{-2} \mathrm{~s}^{-1}\end{array}$ & $\Phi_{\text {app }} / \%$ & $\begin{array}{l}\mathrm{E}_{\text {anode }} \\
\text { (initial) } / \mathrm{V}\end{array}$ & $\begin{array}{l}\mathrm{I}_{\mathrm{ph}} \\
\text { (initial)/mA }\end{array}$ & $\begin{array}{l}\text { Rate/ } \\
\text { mol cm }{ }^{-2} \mathrm{~s}^{-1}\end{array}$ & $\Phi_{\mathrm{app}} / \%$ \\
\hline $\mathrm{OC}\left(\mathrm{O}_{2}\right)$ & 100 & -0.35 & NA & $2.99 \mathrm{E}-09$ & 9.12 & -0.70 & NA & $3.59 \mathrm{E}-09$ & 17.95 \\
\hline OC (Air) & 20 & -0.49 & NA & $2.52 \mathrm{E}-09$ & 7.68 & -0.56 & NA & $2.95 \mathrm{E}-09$ & 14.75 \\
\hline $\mathrm{OC}(\mathrm{OFN})$ & 0 & -0.67 & NA & $2.94 \mathrm{E}-11$ & 0.09 & -0.44 & NA & $6.46 \mathrm{E}-11$ & 0.32 \\
\hline $\mathrm{SC}\left(\mathrm{O}_{2}\right)$ & 100 & +0.46 & -0.06 & 2.94 E-09 & 8.96 & +0.46 & -0.05 & $3.69 \mathrm{E}-09$ & 18.45 \\
\hline SC (Air) & 20 & +0.46 & -0.08 & $2.38 \mathrm{E}-09$ & 7.26 & +0.50 & -0.06 & $3.04 \mathrm{E}-09$ & 15.20 \\
\hline $\mathrm{SC}(\mathrm{OFN})$ & 0 & +0.58 & -0.07 & $7.64 \mathrm{E}-11$ & 0.23 & +0.56 & -0.08 & $8.23 \mathrm{E}-11$ & 0.41 \\
\hline$+1 \mathrm{~V}\left(\mathrm{O}_{2}\right)$ & 100 & 1.00 & 3.90 & 2.99 E-09 & 9.12 & 1.00 & 4.20 & $3.75 \mathrm{E}-09$ & 18.75 \\
\hline + 1 V (Air) & 20 & 1.00 & 4.10 & $2.67 \mathrm{E}-09$ & 8.14 & 1.00 & 4.40 & $3.38 \mathrm{E}-09$ & 16.90 \\
\hline$+1 \mathrm{~V}(\mathrm{OFN})$ & 0 & 1.00 & 4.10 & $5.23 \mathrm{E}-10$ & 1.59 & 1.00 & 5.00 & $6.76 \mathrm{E}-10$ & 3.38 \\
\hline + $2 \mathrm{~V}$ (Air) & 20 & 2.00 & 6.00 & $2.64 \mathrm{E}-09$ & 8.05 & 2.00 & 7.50 & $3.14 \mathrm{E}-09$ & 15.70 \\
\hline + $3 \mathrm{~V}$ (Air) & 20 & - & - & - & - & 3.00 & 9.90 & $2.92 \mathrm{E}-09$ & 14.60 \\
\hline
\end{tabular}

irradiation. Air sparging would be more economical than $\mathrm{O}_{2}$ sparging. With UVA irradiation, the application of a positive potential increased the rate under air sparging by $6 \%$ as compared to OC conditions. With UVA irradiation and $\mathrm{O}_{2}$ sparging, the application of a positive potential did not result in an increase in the rate as compared to that observed for OC conditions. The highest rate achievable for UVA irradiation was $2.99 \times 10^{-9} \mathrm{~mol} \mathrm{~cm}^{-2} \mathrm{~s}^{-1}$ and this was obtained for both $\mathrm{OC}$ or $+1.0 \mathrm{~V}$, with $\mathrm{O}_{2}$ sparging. For UVB irradiation the highest rate of formic acid oxidation was $3.75 \times 10^{-9} \mathrm{~mol} \mathrm{~cm}^{-2} \mathrm{~s}^{-1}$ and this was found with the application of a $+1.0 \mathrm{~V}$ (vs. SCE) potential and $\mathrm{O}_{2}$ sparging, an increase in $5 \%$ as compared to the rate achieved for OC conditions. For UVB irradiation and air sparging, the application of a positive bias of $+1.0 \mathrm{~V}$ (vs. SCE) resulted in an increase in the rate of $15 \%$ compared to OC conditions. Increasing the applied potential more positive than $+1.0 \mathrm{~V}$ resulted in a decrease of the observed rate of oxidation.

The incident light intensity was $3.28 \times 10^{-8}$ Einstein $\mathrm{cm}^{-2} \mathrm{~s}^{-1}$ and $2.00 \times 10^{-8}$ Einstein $\mathrm{cm}^{-2} \mathrm{~s}^{-1}$ for UVA and UVB irradiation respectively. The apparent quantum yields are given in Table 4.9. The highest $\Phi_{\text {app }}$ found with the UVA was $9 \%$ and was achieved under both $\mathrm{OC}$ and $+1.0 \mathrm{~V}$ in $100 \% \quad \mathrm{O}_{2}$. For UVB $\Phi_{\text {app }}=19 \%$ was obtained with $100 \% \mathrm{O}_{2}$ and $+1.0 \mathrm{~V}$ conditions which is more than double that found with UVA irradiation.

\section{Conclusions}

Nanocrystalline films of $\mathrm{TiO}_{2}$ were prepared on borosilicate and ITO coated borosilicate glass and these were used in a stirred tank reactor to investigated the photocatalytic and electrochemically assisted photocatalytic oxidation of formic acid under UVA and UVB irradiation.

The rate of formic acid oxidation under UVB irradiation was $30 \%$ greater as compared to UVA irradiation (catalyst loading of $1.17 \mathrm{mg} \mathrm{cm}^{-2}$ and $\mathrm{O}_{2}$ sparging). A maximum $\Phi_{\text {app }}$ of $9 \%$ was obtained under UVA irradiation with $\mathrm{O}_{2}$ sparging and $\mathrm{OC}$ or $+1.0 \mathrm{~V}$ conditions. A maximum $\Phi_{\text {app }}$ of $20.3 \%$ was obtained under UVB irradiation with $\mathrm{O}_{2}$ sparging with $\mathrm{TiO}_{2}$ on borosilicate glass. $\Phi_{\text {app }}$ was $19 \%$ for $+1.0 \mathrm{~V}, 100 \% \quad \mathrm{O}_{2}$, under UVB irradiation. The increase in oxidation rates and $\Phi_{\text {app }}$ with UVB irradiation could be due to the either the higher extinction coefficient of $\mathrm{TiO}_{2}$ at lower wavelengths and/or the promotion of conduction band electrons to higher more stable states, thus reducing the rate of recombination of charge carriers.

The use of EAP does not increase the rate of oxidation of formic acid where the dissolved $\mathrm{O}_{2}$ concentration is greater than $20 \%$ under conditions of good mass transfer. The use of a UVB source as compared to a UVA source results in a significant increase in the rate of oxidation and increased apparent quantum yields. While the running costs of the UVB source would be the same with respect to electricity, UVB lamps are currently more expensive and a cost analysis of the process would be required to determine the economic viability of employing UVB sources. It remains that EAP may prove beneficial in large-scale reactors where mass transfer limitations exist. Further experiments are ongoing to investigate the interplay between mass transfer and applied potential in these photo-electrochemical cells employing $\mathrm{TiO}_{2}$ electrodes.

\section{Acknowledgments}

The authors thank Degussa for supplying samples of P25, Henk Gilles, Philips lighting, The Netherlands for supplying UV lamps, the engineering technical staff of the University of Ulster for reactor construction, and the Chemical Engineering Department of the University of Groningen, Netherlands, for the design of the reactor. They also thank the European Commission for funding PCA TIE (ENV4-CT970632) and PEBCAT (EVK1-CT-2000-00069). 


\section{References}

1. M.R. Hoffmann, S.T. Martin, W.Y. Choi and D.W. Bahnemann, Chem. Rev. 95 (1995) 69.

2. A. Mills, R.H. Davies and D. Worsley, Chem. Soc. Rev. 22 (1993) 417.

3. A. Mills and S. LeHunte, J. Photochem. Photobiol. A-Chem. 108 (1997) 1 .

4. B. O'Regan, J. Moser, M. Anderson and M. Gratzel, J. Phys. Chem. 94 (1990) 8720.

5. M.F.J. Dijkstra, H. Buwalda, A.W.F. Jongde, A. Michorius, J.G.M. Winkelman and A.A.C.M. Beenackers, Chem. Eng. Sci. 56 (2001) 547.

6. W.Y. Choi, A. Termin and M.R. Hoffmann, Angew. Chem.-Int. Edit. Engl. 33 (1994) 1091.

7. A. Mills and S. Morris, J. Photochem. Photobiol. A-Chem. 71 (1993) 285.

8. U. Stafford, K.A. Gray and P.V. Kamat, J. Catal. 167 (1997) 25.

9. J.G. Sczechowski, C.A. Koval and R.D. Noble, J. Photochem. Photobiol. A-Chem. 74 (1993) 273.

10. M.R. Prairie, L.R. Evans, B.M. Stange and S.L. Martinez, Env. Sci. Technol. 27 (1993) 1776.

11. I.M. Butterfield, P.A. Christensen, T.P. Curtis and J. Gunlazuardi, Water. Res. 31 (1997) 675.

12. T.A. McMurray, J.A. Byrne, P.S.M. Dunlop, J.G.M. Winkelman, B.R. Eggins and E.T. McAdams, Appl. Catal. A-Gen. 262 (2004) 105 .

13. J.A. Byrne, B.R. Eggins, N.M.D. Brown, B. McKinney and M. Rouse, Appl. Catal. B-Environ. 17 (1998) 25.

14. Philips Lighting, Lamps for Special purposes, Report (1999).

15. J.G. Calvert and J.N. Pitts, Photochemistry (John Wiley \& Sons, New York, 1973), pp. 783.

16. A. Mills and J.S. Wang, J. Photochem. Photobiol. A-Chem. 118 (1998) 53.

17. H.T. Chang, N.M. Wu and F.Q. Zhu, Water Res. 34 (2000) 407.

18. A. Blazkova, I. Csolleova and V. Brezova, J. Photochem. Photobiol. A-Chem. 113 (1998) 251.
19. B.V. Blanckenhagen and D. Tonova. Characterisation of thin film materials for optical coatings: Approaches beyond UV/VIS/NIR spectroscopy, Proceedings of the Colloquium on Optical Spectrometry, Berlin, 11-12 November (2002).

20. A.J. Bard and L.R. Faulkner, Electrochemical Methods: Fundamentals and Applications (John Wiley \& Sons, New York, 1980), pp. 577.

21. G. Hodes, I.D.J. Howell and L.M. Peter, J. Electrochem. Soc. 139 (1992) 3136.

22. A. Hagfeldt, H. Lindstrom, S. Sodergren and S.E. Lindquist, J. Electroanal. Chem. 381 (1995) 39.

23. S. Sodergren, A. Hagfeldt, J. Olsson and S.E. Lindquist, J. Phys. Chem. 98 (1994) 5552.

24. K. Vinodgopal, S. Hotchandani and P.V. Kamat, J. Phys. Chem. 97 (1993) 9040.

25. H. Hidaka, Y. Asai, J.C. Zhao, K. Nohara, E. Pelizzetti and N. Serpone, J. Phys. Chem. 99 (1995) 8244.

26. J.A. Byrne and B.R. Eggins, J. Electroanal. Chem. 457 (1998) 61.

27. K. Vinodgopal, I. Bedja and P.V. Kamat, Chem. Mat. 8 (1996) 2180 .

28. H. Gerischer and A. Heller, J. Phys. Chem. 95 (1991) 5261.

29. J.A. Byrne, A. Davidson, P.S.M. Dunlop and B.R. Eggins, J. Photochem. Photobiol. A-Chem. 148 (2002) 365.

30. D.H. Kim and M.A. Anderson, Environ. Sci. Technol. 28 (1994) 479.

31. D.H. Kim and M.A. Anderson, J. Photochem. Photobiol. A-Chem. 94 (1996) 221.

32. R.J. Candal, W.A. Zeltner and M.A. Anderson, Environ. Sci. Technol. 34 (2000) 3443.

33. H. Hidaka, K. Ajisaka, S. Horikoshi, T. Oyama, K. Takeuchi, J. Zhao and N. Serpone, J. Photochem. Photobiol. A-Chem. 138 (2001) 185.

34. J. Krysa and J. Jirkovsky, J. Appl. Electrochem. 32 (2002) 591.

35. H. Hidaka, H. Nagaoka, K. Nohara, T. Shimura, S. Horikoshi, J. Zhao and N. Serpone, J. Photochem. Photobiol. A-Chem. 98 (1996) 73. 